In this isaue

National Periodicals Center

Le Moyne Anderson

Academic/Research Librarian Award

Bibliographic Utilities

ACRL Candidates

ACRL Midwinter Meetings

Continuing Education-XIX

News from the Field

Continuing Education

Opportunities

People

Publications

Classified Advertising

\section{COLLEGE \& RESEARCH LIBRARIES MEINS}

\title{
National Periodicals Center
}

The National Commission on Libraries and Information Science (NCLIS) will sponsor a meeting entitled "The National Periodicals Center Legislation and Implementation: Next Steps" on January 18, 1980, at the Palmer House in Chicago. Among the topics for discussion will be the congressional legislation for a National Periodicals Center (NPC) and the Arthur D. Little, Inc., report on NPC, especially the implications of the System C model described in the Little report.

What is the "System C" NPC, and how does it differ from the technical development plan prepared in 1978 by the Council on Library Resources?

System C is one of the three model systems for the delivery of periodical literature that the consulting firm of Arthur D. Little examined in a report that it prepared for NCLIS last summer. The final version of the report has now been released.

The first model outlined in the report, System $A$, is the system of periodical access that would exist in the $1980 \mathrm{~s}$ in the absence of a periodicals center. In this model no NPC is created, and the need for periodical access is filled by improved interlibrary loan and private document delivery systems.

This System A noninterventionist model comes out surprisingly well in Little's analysis. The report concludes that past studies showing the deficiencies of interlibrary loan as compared to a periodicals center "are mainly oriented to the economics and operations of ILL and library operations in the past-rear-view analyses that do not apply to the world of 1985 and beyond."

By 1985, when an NPC would be in full operation, the Little study predicts, the introduction of on-line interlibrary loan technology will have improved the performance, expanded the scope, and reduced the cost of loan activities to an ex tent not envisioned by past studies. In short, System A would bring about major improvements in access to periodical literature even in the absence of a government-sponsored NPC.

System B, the second model studied in the Little report, follows the general outlines of the Council on Library Resources' technical development plan for a National Periodicals Center. The CLR plan calls for the creation of a centralized, federally subsidized NPC with its own designated collection of both heavily used and less frequently used periodical titles.

System B, according to the Little report, would provide document delivery services at somewhat lower cost to libraries, would provide better assurance of comprehensive service (as compared to System A), and would make possible a comprehensive preservation program. On the other hand, a centralized NPC, says the report, would offer cost benefits only at a high volume of demand, would be susceptible to technological obsolescence when electronic information delivery becomes available in the $1980 \mathrm{~s}$, and, in the worst scenario, would present the danger of a unique "information monopoly."

The last model, System C, envisions the creation of a decentralized National Periodicals Center that would provide location information and network switching services for heavily used periodical titles and would create a central collection and delivery service only for titles not available elsewhere.

System $C$ is presented in the Little study as a compromise between System A and Sysiem B and between the interests of libraries on the one hand and the interests of the information community on the other. From the point of view of libraries, says the report, System A is threatening 
because it has the potential for separating libraries from their patrons as the technology of direct electronic information delivery becomes available.

Conversely, System B, a centralized NPC, would compete directly with private document delivery services and would have the potential for taking over some of the distribution functions traditionally associated with publishing.

System C, on the other hand, while not necessarily the best system in itself, "appears to offer a suitable political compromise between the stock holder interests of both groups" (libraries and the private sector). Under System C, private document delivery firms would be able to continue and expand their services to libraries. Libraries, for their part, would have reliable access to lowuse as well as high-demand materials, a framework for pursuing the goal of preservation, and an assured role as the distribution point for the delivery of documents to users.

\section{COMMENTS WANTED ON PROPOSAL TO DISSOLVE ART SECTION}

At the ALA Annual Conference in June, Betty Jo Irvine, chair of the Art Section, presented to the ACRL Board of Directors on behalf of the Art Section Executive Committee a recommendation (1) that the Art Section be dissolved as of January 1981 and (2) that the 1980 section Executive Committee petition the ALA Council for status as an Art Round Table.

The ACRL board passed a motion approving the recommendation at its June 24 meeting but later rescinded the motion at the request of Irvine so that ACRL members not at the conference might have a chance to express their views about the recommendation.

The report that accompanied the recommendation gave four principal reasons for dissolving the Art Section and transforming it into a round table: (1) the Art Libraries Society/North America (ARLIS/NA), with more than 1,000 members, has become the primary focus for art librarians and subject specialists; (2) few section members attend the Annual Conference programs sponsored by the section; (3) an art section limited to academic librarians in a "type of library" division cannot represent all librarians interested in the visual arts; and (4) a round table representing a cross section of all types of libraries and library activities in ALA would broaden program attendance and participation by all ALA members having an interest in the visual arts.

The proposal to dissolve the Art Section and create a round table is a serious one. Members of
ACRL and particularly of the Art Section should make their views known about this proposal. Please send comments, reactions, or suggestions to Jane Snider, Art Section Chair, Herron School of Art of Indiana University, 1701 N. Pennsylvania St., Indianapolis, IN 46202.

\section{$C む R L N E W S$ PUTS ON A NEW FACE}

Starting in January, CoRL News will have a new cover. In subsequent months, the News will acquire a new typeface and a new body design as well.

These changes are part of a continuing effort to make the News more readable, more timely, and more informative.

In November the News started a "News Brief' feature for late-breaking stories. By using typewritten, camera-ready copy, we can rush "News Briefs" to the printer three weeks after the bulk of the issue has gone to press.

Jim Lockwood, our Washington correspondent, is now preparing his "Inside Washington" report especially for the "News Brief" page. Because this page goes to press at the last minute, he will be able to keep you up to date on late-breaking news from Washington.

Please let us know what you think about the new appearance of the News or about its editorial content. Any comments, criticisms, or suggestions that you might offer would be most appreciated. $-E d$.

College \& Research Libraries News is published by the As. sociation of College and Research Libraries, a division of the American Library Association, as 11 monthly (combining July-August) issues, at $50 \mathrm{E}$. Huron St., Chicago, IL 60611 . Annual subscription: $\$ 5$; or to members of the division, $\$ 2.50$ included in dues. Single copies and back issues, $\$ 2$ each. Second-class postage applied for at Chicago, Illinois, and at additional mailing offices.

Editor: Jeffrey T, Schwedes, ACRL/ALA, 50 E, Huron St. Chicago, IL 60611; (312) 944-6780. Ext. 286. President. ACRL: LeMoyne W. Anderson. Executive Secretary, ACRL: Julie A. Carroll Virgo.

Production and circulation office: $50 \mathrm{E}$. Huron St. Chicago IL 60611. Display advertising should be sent to Leona Swiech, Advertising Traffic Coordinator. ALA at above address. Send classified ads to ACRL. Change of address and subscription orders should be addressed to Coliege \& Research Libraries News, for receipt at the above address at least two months be fore the publication date of the effective issue.

Inclusion of an article or advertisement in C\&RL News does

not constitute official endorsement by ACRL or ALA

A partial list of the services indexing or abstracting the contents of C\&RL News includes: Current Contents: Social \& 8 e havioral Sciences, Current Index to Journals in Education. in formation Science Abstracts; Library \& Information Science Abstracts; Library Literature, and Social Sciences Citation InAbstra.

(C)American Library Association 1979. All material in this journal subject to copyright by the American Library Association may be photocopied for the noncommercial purpose of scientific or educational advancement. 